\title{
Research on Politeness Strategies in International Business Correspondence
}

\author{
Hui $\mathrm{Wu}^{1, \mathrm{a}}$ and Dan $\mathrm{Wu}^{2, \mathrm{~b}}$ \\ ${ }^{1}$ Faculty of Foreign language, Hubei Engineering University, Hubei Xiaogan, China \\ ${ }^{2}$ Wenchang Middle School, Hubei Xiaogan, China \\ a443138446@qq.com, b1960516319@qq.com
}

Keywords: International business correspondence; Communication; Politeness; Maxim

\begin{abstract}
International business correspondence, which has been frequently used in international business, is an effective communication tool for contacting customers. Being an effective communication tool, politeness has been employed in business correspondence for enhancing communication and understanding to reach the target of successful business transaction. The six maxims in Leech's theory of politeness are discussed based on the level of vocabulary, sentence and passage structure as well as the characters of business correspondence in the dissertation.
\end{abstract}

\section{国际商务函电中礼貌原则运用研究}

\author{
吴慧 ${ }^{1, a}$, 吴丹 ${ }^{2, b}$ \\ 1. 湖北工程学院外国语学院, 中国 湖北 孝感 432000 \\ 2. 湖北省孝感市文昌中学, 中国 湖北 孝感 432000 \\ a443138446@qq.com, b1960516319@qq.com
}

摘要: 国际商务函电被广泛用在国际贸易中联系顾客, 是与客户沟通的有效工具。作为一种 有效的沟通工具, 礼貌原则被 大量运用在国际商务函电中, 用来促进沟通交流, 达到成功 交易目的。本文结合 Leech 礼貌原则里的六条准则, 从常用词语, 句子和语篇层面具体分析 探讨其运用特点, 阐述国际商务函电写作中的特点。

关键词: 国际商务函电; 沟通; 礼貌; 准则

\section{1. 前言}

外贸英语函电是公司用以联系顾客的常见工具, 在国际对外贸易中发挥主要沟通作用。撰写 外贸英语函电, 除了要注意语法, 句法和词汇, 还要特别注意外贸英语函电的书写特点。商务 英语写作的撰写者在态度方面要记住: 清晰; 简洁; 真诚; 友善; 自然; 强调正面要点; 淡 化负面影响 [1]。在外贸英语函电中, 为了强调正面要点, 做到真诚友善, 礼貌原则被大量 使用。礼貌原则可以有效用来缓解紧张气氛, 赢取对方信任, 是建立合作关系的重要手段。 商务交际中言语表达者经常有意识地选择和使用语言来实施自己的行为, 表达自己的态度, 评价事物优劣 [2]。本文就外贸函电中常见词, 句, 语篇特点具体结合礼貌策略的使用进行 探讨研究。

\section{2. 礼貌原则}

英国语言学家 G. Leech 的言语交际的礼貌原则被普遍运用于语言研究中. Leech 的礼貌理论 包括六条准则: (1) 策略准则 (tact maxim) : 使他人受损最少, 他人受惠最大; (2) 宽容准则 (generosity maxim): 使自身受惠最少, 自身受损最大; (3) 赞誉准则(approbation maxim): 尽力缩 
小对他人的贬损, 夸大对他人的赞扬; (4) 谦虚准则(modesty maxim): 夸大对自己的贬损, 尽力 缩小对自身的赞扬, ; (5) 赞同准则 (agreement maxim): 尽力缩小自身和他人之间的分歧, 夸大 自身与他人之间的一致; (6) 同情准则(sympathy maxim): 夸大对他人的同情, 尽力缩小自身对 他人的厌恶, 。其中, 策略准则和宽容准则一起使用, 赞誉准和谦虚准则一起使用。遵循其中 之一, 那么另一句话必然遵循另一准则。商务信函作为会话交际的一种书面形式, 它的写作 原则是与语用原则是一致的, 礼貌原则贯穿商务语言交际活动的基本语用准则, 是商务活动 的必然要求, 语用学的礼貌原则被广泛用于各类商务信函来促进贸易发展。

\section{3. 函电语言特点与礼貌原则}

\section{1 . 转折连词与赞同准则}

连词在商务函电中被广泛的使用, 在句子中能让语气更加平和委婉, 特别是在传达负面消息 时, 连词被用来有效的缓解紧张氛围, 常与赞同准则, 同情准则一起使用。如:

(1)We appreciate the good quality of these garments, but unfortunately your prices appear to be on the high side even for garments of this quality.

在此句中, 首先是赞同对方产品质量好, 随后用连词“but”对句子进行一个转折, 缓解负面消 息的影响。随后用 “unfortunately”表示同情，用同情的口气传递负面的信息。

(2)However, we'd like to emphasize that your L/C must reach here by the end of this month. Otherwise shipment has to be delayed.

此句中，用连词 "However" 开头用来吸引对方的注意，

(3)We shall, therefore, be glad if you will abstain from consigning the goods, but we shall not fail to indemnify you in the event of future requirement.

句子中委婉的用 "therefore”转折表达交易的条件, 体现出了赞美原则。在后半句用 "but”强 调了对对方的关切和同情，会对对方做出补偿。整个句子让对方感到关怀和诚意。

(4)We are very interested in the different types of paints you offer and have decided to place a trial order for the following, on the terms stated in your letter, but only if you can guarantee dispatch in time to reach us by the end of this month.

此句中, 先是对对方产品的赞扬, 接着连词转折提供条件, 强调交易进行的条件。这样避免 了在句子开头直接阐述交易条件的尴尤和冲突。

从以上例句分析中我们可以看出, 在商务函电中, 转折连词被大量的使用, 其中使用频率最 高的是 but, 其次是 therefore, however. 这些连词常被用来传达负面的消息, 表达对他人的尊 重, 让语气平和舒缓。

3.2. 介词短语的使用与策略准则

商务英语作为一种独特文体, 其特点主要表现于频率和分布上有所不同, 也就是说某些语言 现象使用的次数比其它的语言现象多。商务英语在短语结构上表现为高度严谨凝炼, 这就需 要使用大量的介词短语, 在 Leech 理论中, 策略准则是这六个准则中最重要的。是避免冲突 的一种手段 [3]。在商务函电中, 介词短语的使用不仅能使句子读起来朗朗上口, 增加信函 的正式和礼貌度, 还能更好体现作者意图, 结合策略准则使用, 让信函彬涁有礼, 流畅得体。 (1)On the combined cost/benefit basis, we have decided to accept the other company's offer.

在句子开头, 作者使用介词短语开头, 避免了正面的冲突, 强调此举是在综合考虑基础之上, 体现了策略准则的使用。

(2)We shall continue to place orders and will invite your quotations on this line in the future. 文末介词短语的使用让句子显得正式, 专业性强, 给人以对方非常专业的好印象。

(3)We should appreciate a reply at your earliest convenience.

强调在对方的利益之下, 对方最方便的时候给予答复, 充分体现了对方最方便的时候, 体现 了策略准则。 
(4)With reference to your letter of May 8 enquiring for coke, we enclose our quotation for your consideration and trust you will find our prices acceptable.

此类开头, 常用在函电中。此介词短语的使用, 突出具体信件, 强调对方信件的重要性, 吸 引读者注意。这种开头符合礼貌原则中的策略准侧和宽容准则, 强调对对方的有利。

大量介词短语的使用, 能增加句子的正式感, 使得否定程度弱化, 为对方留下考虑回旋的余 地。如让句子读起来更加感觉真诚, 有亲切感, 显得礼貌。

3.3. 委婉语的使用

委婉语是用一种使人感到愉快的或含糊的说法, 模糊限制语中的缓和型模糊限制语的语用功 能是使说话人得以恪守合作原则或礼貌原则等, 在清楚表达会话含义的情况下避免将意见强 加于人, 避免过于武断 [4]。委婉语一词, 意为 “好听的话” 。即用一种不明说的, 能使人感 到愉快的或含糊的说法, 代替具有令人不悦的含义或不够尊敬的表达方法 [5]。商务人员在 商务函电写作中常借助于委婉语和委婉表达方式这一重要的修辞手段, 含蓄、委婉地表达自 己的观点, 提出请求, 以利于创设良好的商务环境, 达到交易双方各自预期的目的。在函电 中, 许多句子都有固定的委婉语来表示, 常见有 suggest, propose, regret 等词语。这些 词语的引用通常用在提到重要信息时候, 一方面是引起读者的关注, 另一方面是做到礼貌待 人，建立良好商务氛围。例如:

(1)We suggest payment by bill of exchange drawn on us at 30 days after sight.

(2)We propose to pay by Bill of Exchange at 30d/s, document of you Invoice No.ST123 of September 20,2003.

此外，在业务洽谈表达主观意见或看法时，通常用到“think”、“hope”、“regret”、“please”等动

词, 使表达的观点或提出的要求不主观武断, 语气委婉, 但观点鲜明。例如:

We regret having to inform you that although it is our desire to pave the way for a smooth development of business between us, we cannot accept payment by D/A.

这些语言可以避免直白的语言伤害合作双方的感情, 有效保护双方的合作积极性, 避免不必 要的纠结与损失, 从而达到更好经济往来的目的 $[6]$ 。

\section{4. 句子与礼貌策略}

\section{1. 肯定否定句式的使用}

在商务英语中, 否定句式被经常使用表示肯定寓意, 即所谓谦逊准则。例如:

(1)If you are intersted in any other items, please do not hesitate to let us know .

(2)What we have quoted is really the lowest, we regret being in no position to reduce our price . 此外用肯定句式表示否定寓意, 遵循赞美准则。

(3)We are very interested in the different types of paints you offer and have decided to place a trial order for the following, but only if you can guarantee dispatch in time to reach us by the end of this month.

(4)We find your price too high and out of line with the prevailing market level.

3.2. 疑问句的使用与礼貌策略

在商务英语函电中, 疑问句被大量的用在询价, 发盘和还盘中, 用来提出建议, 要求。疑问 句的使用可以让语气委婉含蓄, 更加人性化, 句子读起来自然得体。常见的疑问句式如下:

Will you please state your earliest delivery time, terms of payment, price lists?

May we suggest that you requite us a lower price?

Would you like to reduce your rising domestic fuel costs?

这些例句都是提出建议和要求, 为了避免直接提出给对方造成的不悦和武断, 用疑问句对方 更能接受。这符合礼貌策略中的宽容策略的使用。询问对方观点, 征求对方观点, 站在让自 己受惠最少，受损最多的角度来进行交易谈判。 


\section{3. 时态的使用}

英语中用进行体可表达委婉的语气。一些动词, hope, think, wonder, want 等, 其进行体比一般体 更客气些。

例如: I wonder if you could lower the price.

I am hoping if you could lower the price.

上述例句中, 后一句用到进行体, 比前一句更谦恭, 因而更显得有礼貌

We write to you in the hope that we can open up business relations with your firm

We're writing to you in the hope that we can open up business relations with your firm.

此句子中，后面的句子用到进行体，比前面的句子语气更加礼貌得体。

\section{5. 语篇特点}

作为一种专门用途英语, 商务英语函电 “其应用范围十分广泛、庞杂, 在长期使用过程中, 根据事务的性质和应用的场合逐渐形成了若干固定的篇章格式, 即固定的篇章结构形式和言 语程式” [7]。从语篇特点来看, 整个函电都遵循一定的礼貌策略。具体分析以下两篇函 电可以看到礼貌策略的使用。

\section{Dear Sirs:}

We have carefully considered your order of 3 September but very much regret that we cannot accept it. The prices we quoted in our letter of 1 September leave us with only the smallest of margins and they are in fact lower than those of our competitors for goods of the similar quality.

The pet toys produced in our factory undergo a special process. The fact that we are the largest suppliers of these products in this country is in itself evidence of the good value of our products.

If, having given further thought to the matter, you feel you cannot accept our offer, we hope it will not prevent you from approaching us on some other occasions. We shall always be very pleased to hear from you and will carefully consider any proposals likely to lead to business between us.

Yours faithfully[8]

首先在函电开头, 对于拒绝别人的信函, 都是采用策略准则和宽容准则, 具体的表示自己已 经仔细思考，即便是在自己受损最大的情况下，仍然不能接受对方的条件。

本文的第二段, 看似好像违背了礼貌策略, 写信方在夸赞自己的产品质量好, 是国内该类产 品的最大供应商。其实结合第一段来看, 第二段是在暗示自己利益已经受到了很大损失。符 合谦虚准则，写信者尽力缩小对自身的赞扬, 尽力夸大对自己的贬损。

信函结尾借助表达对后期合作的期待和愿望, 作者用到了赞同准则和同情准则, 对对方如果 不能接受, 表示理解。对对方有可能出现的还盘, 以及还盘中的种种附加条件, 从站在对方 的角度来考虑, 减少对他人的厌恶, 表示会很高兴接受对方的还盘并且考虑。是同情准则的 典型运用。从以上信函可以看出, 商务写作者要有扎实的语言、文化和专业功底, 又要拥有 高超的修辞技巧，让合作方觉得礼貌真诚，不唐突，不献媚，不造作，文雅有度 [9]。

下面是有关拒绝对方订单的信件:

Dear Mr. Wang:

Thank you for your order of May 6 for six hundred sets of "Peony" Television Sets, but since you make delivery before Christmas a firm condition, we deeply regret that we cannot supply you as we have done on so many occasions in the past.

The manufactures are finding it impossible to meet current demand for this very popular set. We ourselves placed an order for 200 sets a month ago, but were informed that all orders are being met in strict rotation and that our own could not be dealt with before the beginning of February.

I gather from your telex received this morning that your customers are unwilling to consider other makes. May I suggest that you try China National Light Industrial Products Import \&Export Corporation in Beijing. They may be able to help you.

Sincerely yours, 信函的开头道出感谢, 表示对被人的感激和订单的认可, 用到策略准则。开头的后半句表示 
遗憾不能提供物品，用到宽容准则表示对对方的非常遗憾。

在信函的第二段, 具体拒绝原因呈现在读者面前。这个部分是客观的阐述原因, 但是这个解 释背后是谦虚准则的运用。通过对工厂生产能力的介绍，表示的确没有能力接单。

信函结尾, 通过对对方的关切以及提出相关的解决办法, 表示出自己的确是诚意想接单但是 没有能力，强调事实的不如意，即所谓同情准则。运用到了赞同准则和同情准则。

从以上这两篇外贸函电的分析来看, 礼貌原则的运用贯穿函电运用的过程, 有些语句看似与 礼貌原则无关, 但是背后确是礼貌原则的运用。为了维持双方的良好合作关系, 发信方注意 运用恰当的措词和语气, 尽量维护对方的消极面子 [10]。

\section{6. 结语}

礼貌原则贯穿函电写作过程, 具体分析其运用有利于国际贸易中成功建立合作关系。在国际 商务活动中, 我们的语言表达要做到自然得体; 对词语, 句型, 语篇要仔细卙酌, 要能做到 情真意切, 不卑不六。在函电的撰写过程中应时刻注意到礼貌这一特点, 充分考虑到信函中 所使用的语气会给读者留下什么样的印象, 产生什么样的影响, 只有这样才能让所要表达的 信息为对方欣然接受, 建立良好业务关系。总之, 语言礼貌策略在商务活动中发挥重要作用, 从商务交际中恰当地运用礼貌语用策略, 可以促使他们的国际商务贸易更加顺利地进行。

\section{参考文献}

[1] 潘琪, 曹瑞. 商务英语写作经典案例详解[M]. 北京：中国宇航出版社, 2009：5.

[2] 苏姗, 娄志刚. 商务英语函电句子主语选择与功能分析 [J]. 内蒙古农业大学学 报,2010(03),387

[3] 何自然, 苒永平. 语用学概论(修订本)[M].湖南:湖南教育出版社,2002:227

[4] Leech Geoffrey N. Principles of Pragmatics [M].London:Longman Group Limited,1983: 132

[5] 毛忠霞.商务英语信函写作中的礼貌策略探析[J].湖南科技学院学报,2009(11):200.

[6] 陈 菲, 李 婷, 模糊语言在国际商务英文函电中的应用 [J]. 湖北广播电视大学学 报,2012(10):92.

[7] 王德春,陈晨.现代修辞学 [M] . 上海: 上海外语教育出版社,2001: 113 .

[8] 胡鉴明.商务英语函电[M].北京：中国商务出版社，2008：75.

[9] 邱丽洪. 浅析商务英语函电中修辞的特征[J].长沙大学学报, 2011(07):90.

[10]李文梅. 面子理论在外贸英语函电中的应用研究[J].四川教育学院学报, 2010(03):104.

\section{References}

[1] Qi pan,Rui cao.Case Study:Business Writing[M]. Beijing:China Astronautic Publishing House 2009: 5

[2] Shan Su, Zhigang Lou.Analysis of subject selection and function in business correspondence [J]. Journal of InnerMongolia Agricultural University,2010(03),387

[3] Ziran He, Yongpin Ran. An Introduction to Pragmatics [M]. Hunan: Hunan Education Publishing House, 2002:227

[4] Leech Geoffrey N. Principles of Pragmatics [M]. London: Longman Group Limited,1983 : 132

[5] Zhongxia Mao. Politeness Strategies in Writing Business English Letters [J].Journal of Hunan 
University of Science and Engineering, 2009(11):200.

[6] Fei Chen, Ting Li, Application of Vague Language in International Business English Correspondence[J].Journal of Hubei Radio \&Television University,2012(10):92.

[7] Deichun Wang, Chen chen. Modern Rhetoric [M].Shanghai: Shanghai Foreign Language Education Press, 2001: 113.

[8] Jianming Hu. Business English Correspondence [M]. Beijing: China Commerce and Trade Press,2008: 75.

[9] Lihong Qiu. Analysis of Rhetoric in Business English Correspondence [J]. Journal of Changsha University, 2011(07):90.

[10]Wenmei Li. Application of Face Theory in Foreign Trade English Correspondences [J].Journal of Sichuan College of Education,2010(03):104.

作者简介: 吴慧 (1978-), 女, 湖北孝感, 湖北工程学院外国语学院, 讲师, 硕士学位。研 究方向为语言学和教学法。 